\title{
FRANCISZKAŃSKI „NOWY KORBUT” O KUSTODII ZIEMI ŚWIĘTEJ I JEJ POLSKICH WSPÓLPRACOWNIKACH
}

\author{
A. J. Szteinke OFM, Polscy Bracia Mniejsi w służbie Ziemi Świętej \\ (1342-1995). Poznań 1999, ss. 207.
}

Praca o. Anzelma Szteinkego OFM składa się z dwu części: próby syntetycznego omówienia problemu na przestrzeni ponad sześciu wieków oraz części biograficznej. W początkowej fazie był to referat o franciszkańskiej Kustodii Ziemi Świętej, wygłoszony przez autora podczas sesji naukowej na temat: „Jerozolima w kulturze europejskiej” (Warszawa, 14-17 maj 1996). O. Szteinke, który już od 35 lat pracuje nad problematyką historyczną Ziemi Świętej, a w latach 1972-1987 był komisarzem krajowym Kustodii Ziemi Świętej i prowincjałem swojej prowincji Matki Bożej Anielskiej (1978$-1984)^{1}$ - w swoim referacie skoncentrował się na omówieniu polskiego udziału w historii Kustodii, i to jego opracowanie zostało opublikowane w księdze pamiątkowej pt. „Jerozolima w kulturze europejskiej” (Warszawa 1997). Nie poprzestał jednak na tym, ale poszerzył bazę źródłową opracowanego przez siebie tematu i uzupełnił jego literaturę. Na tej podstawie przeredagował i znacznie poszerzył swój artykuł z księgi pamiątkowej ${ }^{2}$.

Część biograficzna powstałego w ten sposób dzieła, stanowi swego rodzaju leksykon polskich Braci Mniejszych (Franciszkanów prowincji Matki Bożej Anielskiej i Bernardynów), związanych z Ziemię Świętą „którzy pracowali na rzecz Ziemi Świętej, w kraju swego zamieszkania, tworząc zaplecze duchowe i materialne dla działalności misjonarzy w Palestynie". Obok misjonarzy i braci zajmujących się z urzędu troską o Kustodię Ziemi Świętej, weszli tu również ,autorzy i wydawcy przewodników po Ziemi Świętej oraz opublikowanych pamiętników, wspomnień i reportarzy z pielgrzymek, oraz historyków badających relacje Polska a Ziemia Swięta" ${ }^{\text {. }}$.

Wspominając Polaków najbardziej zasłużonych dla Ziemi Świętej autor umieścił wśród nich Mikołaja Krzysztofa Radziwiłła zwanego Sierotką, oraz Mikołaja Zebrzydowskiego, wojewodę krakowskiego. Pierwszy z nich odbył pielgrzymkę do Ziemi Swiętej w 1583 r., którą opisał w diariuszu pt. „Peregrynacje abo pielgrzymki” (Kraków 1607). Złożył pokaźną sumę na

${ }^{1}$ Biografia naukowa. W: Polscy Bracia Mniejsi..., s. 171-173.

${ }^{2}$ Tamże, s. 5n.

${ }^{3}$ Tamże, s. 7.

${ }^{4}$ Mikołaj Krzysztof Radziwiłł (Sierotka), Hierosolimitana peregrinatio ... Nicolai Ch. Radzivilli ... Brunsbergae (Apud G. Schőnfels) 1601. - Kolejne wydania tegoż w j. łacińskim: Antwerpiae 1614; (b.m.w.) 1753; Cossoviae 1756; - W języku polskim: Peregrinacia abo 
potrzeby Kustodii. Z kolei M. Zebrzydowski był fundatorem „Jerozolimy na polskiej ziemi" czyli klasztoru Bernardynów i Dróżek Męki Pańskiej w Kalwarii Zebrzydowskiej w 1604 r. ${ }^{5}$ Obaj zostali obdarzeni tytułem prokuratora (względnie syndyka) Ziemi Świętej.

Poczatkowe ramy czasowe opracowania wyznacza data powstania franciszkańskiej Kustodii Ziemi Świętej w 1342 r. Data końcowa to czas ukończenia kwerendy przez autora i jego współpracowników.

Czytelnik interesujący się miejscami świętymi w Palestynie oraz dziejami Polaków z nimi związanych znajdzie w opracowaniu bardzo cenny materiał z zakresu polskich peregrynacji i opisów Ziemi Świętej, od najstarszego opisu w języku łacińskim o. Anzelma z Krakowa OFM (zwanego Polakiem) z 1512 r. $^{6}$ do wydanego w latach 80-tych obecnego wieku pt. „W Ojczyźnie Chrystusa. Przewodnik po Ziemi Świętej” D. Baldiego (w tłumaczeniu z j. włoskiego A. Kowalskiego), wydrukowanego staraniem o. W. Michalczyka OFM, A. J. Błachuta OFM i Z. Stysia OFM (Kraków-Asyż 1982) i najnowszych form peregrynacji do Ziemi Świętej w postaci pielgrzymek organizowanych w skali kraju (zob. Podworski Antoni Gerwazy OFM. W: „Polscy Bracia Mniejsi...”, s. 139-140).

Wiestaw Franciszek Murawiec OFM

pielgrzymowanie do Ziemi Świętej ... Mikołaja Krzysztofa Radziwitta, ksiażęcia na Otyce y Nieświeżu, hrabie na Szydtowcu, wojewody wileńskiego. A przez x. Andrzeja Wargockiego na polski przetożona. Kraków (U Szymona Kempiniego) 1607. - Następne wydania tegoż miały miejsce: w Krakowie 1611; w Krakowie 1617; w Krakowie 1628; w Krakowie 1683; (b.m.w.) 1745. - W języku niemieckim: Juengst geshehene Hierosolimitanische Reys und Wegfarth das ... Nicolai Ch. Radivili ... Meintz (bey B. Lippen) 1603.

${ }^{5}$ O Mikołaju Zebrzydowskim por. H. E. W y c z a w sk i OFM, Kalwaria Zebrzydowska. Historia klasztoru Bernardynów i kalwaryjskich Dróżek. Kalwaria Z. 1987 (Szczególnie rozdz. 2. pt. "Zebrzydowscy").

${ }^{6}$ Tytul tego opisu: Terrae Sanctae apertior descriptio fratris Anselmi OFM. W: Jan Stobnic a (Stobniczka), Introductio in Ptholomei Cosmographiam ... Cracoviae (per F. Unglerum) 1512, k. 29v.

${ }^{7}$ Kolejne wydanie tegoż: Kraków-Asyż 1993. 